\title{
Gambaran Fisiologis Kadar Kolesistokinin Tikus Wistar (Rattus norvegicus) Jantan Umur 1 Bulan
}

\section{The Physiological Overview Levels of Cholecystokinin on 1-Month-Old Male Wistar Rats (Rattus norvegicus)}

\author{
Amelia Hana*, Claude Mona Airin \\ Departemen Fisiologi Fakultas Kedokteran Hewan, Universitas Gadjah Mada. \\ Jl. Fauna No. 2, Karangmalang, Yogyakarta 55281 Tel/Fax: +62 274560864. \\ *Email : hana_amy@ugm.ac.id
}

Diterima 27 Februari 2018 / Disetujui 16 Maret 2018

\begin{abstract}
ABSTRAK
Peran fisiologis kolesistokinin (CCK) adalah pengendalian fungsi gastrointestinal. Kolesistokinin akan disekresikan oleh sel endokrin usus sebagai respons terhadap makan yang kekurangan atau kelebihan lipid dan protein. Tujuan dilakukannya penelitian ini adalah untuk mengetahui gambaran fisiologis kadar kolesistokinin tikus Wistar umur 1 bulan. Dua puluh ekor tikus Wistar (Rattus norvegicus) jantan, umur 1 bulan, diadaptasikan selama 7 hari dalam kandang individu dengan pakan AD II dan minum air ad libitum. Kemudian dilakukan penimbangan berat badan dan pengambilan darah lewat vena orbitalis untuk pengukuran kadar CCK plasma, kadar glukosa darah, dan kadar kolesterol darah. Hasil penelitian menunjukkan bahwa berat badan rata-rata tikus adalah 54,6 $\pm 3,36$ gram, kadar kolesistokinin $259,61 \pm 104,60 \mathrm{pg} / \mathrm{mL}$, kadar glukosa darah $125,35 \pm 20,36 \mathrm{mg} / \mathrm{dL}$ dan kadar kolesterol 74,5 $\pm 14,73 \mathrm{mg} / \mathrm{dL}$. Setelah dianalisis korelasi disimpulkan bahwa pada tikus jantan normal umur 1 bulan kadar CCK plasma tidak berkorelasi dengan kadar glukosa darah dan kadar kolesterol darah.
\end{abstract}

Kata kunci : kolesistokinin, glukosa, kolesterol, berat badan, tikus jantan

\begin{abstract}
The physiological role of cholecystokinin is to control of gastrointestinal function. Cholecystokinin (CCK) will be secreted by intestinal endocrine cells in response to eating that deficient or excess lipid and protein. The purpose of this study was to determine the physiological picture of cholecystokinin level on rats. Twenty rats of male Wistar (Rattus norvegicus), 1 month of age, were adapted for 7 days in individual cages with $\mathrm{AD}$ II feed and drinking ad libitum water. Then weigh the body weight and blood collection through orbital veins for measurement of plasma CCK levels, blood glucose levels, and blood cholesterol levels. The results showed that the average body weight of rats was $54.6+3.36$ gram, cholecystokinin $259,61+104,60 \mathrm{pg} / \mathrm{mL}$, blood glucose level 125,35 +20,36 mg/ dL and cholesterol 74, $5+14,73 \mathrm{mg} / \mathrm{dL}$. After correlation analysis can be concluded that in normal male rat 1 month plasma CCK level not correlated with blood glucose levels and blood cholesterol levels.
\end{abstract}

Keywords : cholecystokinin, glucose, cholesterol, body weight, male rats

\section{PENDAHULUAN}

Kolesistokinin (CCK) adalah hormon gastrointestinal, mempunyai fungsi terhadap gastrointestinal dan imunoregulasi. Kolesistokinin dapat digunakan sebagai bahan ajuvan untuk memodulasi respon inflamasi dan mencegah komplikasi sistemik selama sepsis. Peningkatan kadar CCK plasma pada syok endotoksik untuk mencegah kardiovaskular kolap dan hipoperfusi jaringan (Saia et al, 2014).

Peran utama CCK sebagai hormon dan neuropeptida, secara perifer dalam sistem gastrointestinal dan secara sentral pada sistem saraf dalam pengaturan kenyang, kecemasan, dan sistem neuroendokrin, dalam penyesuaian parakrin 
dari sekresi aldosteron (Malendowicz et al., 2001; Poosti et al., 2000). Peran fisiologis lain dari CCK adalah pengendalian fungsi gastrointestinal melalui integrasi penyerapan nutrisi dan metabolisme nutrisi melalui stimulasi sekresi endokrin pankreas dan pertumbuhan pankreas (Chowdhury dan Rayford, 2001).

Pada mamalia, kolesistokinin (CCK) disekresikan dalam berbagai jaringan, termasuk saluran pencernaan (duodenum dan usus halus) dan sistem saraf perifer dan pusat (Sekiguchi, 2016; Agersnap dan Rehfeld, 2015). Kolesistokinin yang bekerja pada serabutt aferen vagal memediasi berbagai fungsi fisiologis. Aktivasi vagal afferent CCK meningkatkan ingatan afektif terkait viseral (Cao et al., 2012).

Pengukuran kadar kolesistokinin normal pada tikus jantan umur 1 bulan disertai dengan berat badan, kadar glukosa darah dan kadar kolesterol darah belum lengkap dilaporkan, sehingga data yang diperoleh dapat menjadi informasi untuk penelitian terhadap perubahan pemberian lemak dan protein dalam makanan tikus.

\section{METODE PENELITIAN}

\section{Alat dan Bahan}

Alat yang digunakan adalah kandang tikus individu ukuran $13 \times 24 \times 16 \mathrm{~cm}^{3}$ lengkap dengan tempat makan dan tempat minum; Rat CCK (Cholecystokinin) Elisa kit, Finetest, China, No. Katalog ER0372 untuk menentukan kadar CCK plasma tikus; Accu-chek ${ }^{\circledR}$ Advantage, Roche Diagnostic, Germany untuk menentukan kadar glukosa darah; dan Cholesterol FS. DiaSys Diagnostic Systems GmbH. Germany untuk menentukan kadar kolesterol darah.

Bahan yang digunakan adalah 20 ekor tikus Wistar (Rattus norvegicus) jantan, umur 1 bulan yang diperoleh dari Unit Pengembangan Hewan Percobaan (UPHP) UGM; pakan tikus AD II (comfeed Pars 53\% dengan kandungan air 12\%, protein $11 \%$, lemak $4 \%$, serat $7 \%$, abu $8 \%$, Ca $1,1 \%$, fosfor $0,9 \%$, antibiotika, coccidiostat $53 \%$, tepung terigu $23,5 \%$, dan air $23,5 \%$, produksi PT Japfa Comfeed Indonesia, Sidoharjo).

\section{Cara Perlakuan Hewan Uji}

Dua puluh ekor tikus jantan, umur 1 bulan diadaptasikan selama 7 hari dalam kandang individu pada suhu rata-rata sekitar $24-26^{\circ} \mathrm{C}$, kelembaban rata-rata 58-62\%, dan diterangi lampu neon. Pakan yang diberikan adalah pakan AD2A (produksi PT Japfa Comfeed Ind, Tbk Unit Sidoharjo) dalam bentuk pelet dan air bersih ad libitum. Setelah adaptasi dilakukan penimbangan berat badan dan pengambilan darah lewat vena orbitalis untuk pengukuran kadar kolesistokinin (CCK) plasma, dan pengambilan darah lewat vena coccigea untuk mengukur kadar glukosa darah, dan kadar kolesterol darah.

\section{Analisis Data}

Data berat badan, kadar CCK plasma, kadar glukosa darah, kadar kolesterol darah dianalisis korelasi dengan menggunakan uji PearsonSPSS 16.

\section{Menentukan kadar kolesistokinin}

Metode pengukuran CCK menggunakan enzym-linked immunosorbent assay (Elisa) sesuai prosedur manual Fine test rat $\mathrm{CCK}$ (Cholecystokinin) Elisa Kit Cat. No. ER0372 sebagai berikut : Larutan $0,1 \mathrm{~mL}$ standard 1000 $\mathrm{pg} / \mathrm{mL}, 500 \mathrm{pg} / \mathrm{mL}, 250 \mathrm{pg} / \mathrm{mL}, 125 \mathrm{pg} / \mathrm{mL}, 62.5$ $\mathrm{pg} / \mathrm{mL}, 31.25 \mathrm{pg} / \mathrm{mL}, 15.6 \mathrm{pg} / \mathrm{mL}$ dimasukkan ke dalam standard sumuran. Ditambah $0.1 \mathrm{~mL}$ sampel/ standard dilution buffer ke dalam kontrol (zero) well. Ditambah $0.1 \mathrm{~mL}$ plasma ke dalam sampel sumuran. Plate ditutup dengan penutup dan inkubasi pada suhu $37^{\circ} \mathrm{C}$ selama 90 menit. Penutup dan isi plate dibuang, plate ditepuk di atas kertas saring penyerap. $0.1 \mathrm{~mL}$ Larutan Biotin-detection antibody yang telah diencerkan ditambahkan ke atas sumuran (standard, sampel dan zero sumuran). Plate ditutup dan diinkubasi pada suhu $37^{\circ} \mathrm{C}$ selama 60 menit. Penutup dibuang, dan plate dicuci $3 \mathrm{x}$ dengan larutan Wash Buffer. Ditambahkan $0.1 \mathrm{ml}$ larutan SABC yang telah diencerkan ke dalam masing-masing sumuran, plate ditutup dan diinkubasi $37^{\circ} \mathrm{C}$ selama 30 menit. Penutup dibuang dan dicuci $5 \mathrm{x}$ dengan larutan Wash Buffer, dan pada tiap kali pencucian larutan 
dibiarkan berada di sumuran selama 1-2 menit. Ditambahkan $90 \mu \mathrm{L}$ larutan TMB substrat ke dalam setiap sumuran, plate ditutup dan diinkubasi $37^{\circ} \mathrm{C}$ pada ruang gelap selama 15-30 menit. Ditambahkan $50 \mu \mathrm{L}$ larutan stop ke dalam masingmasing sumuran dan dicampur merata. Warna akan segera berubah menjadi kuning. Absorbansi O.D. dibaca pada 450nm dengan elisa reader segera setelah penambahan larutan stop. Untuk kalkulasi, (O.D. 450 relatif) $=$ O.D.450 setiap sumuran - O.D.450 sumuran kontrol. Kurve standard dapat diplott sebagai O.D. 450 relatif setiap larutan standard (Y) vs. Masing-masing konsentrasi larutan standard (X). Konsentrasi CCK sampel dapat diinterpolasi dari kurva standar.

\section{Menentukan kadar glukosa darah}

Metode pengukuran kadar glukosa darah sesuai prosedur manual Roche REF 0 5234441021ACCU-Chek Active Blood Glucose Meter sebagai berikut : sampel darah yang diambil lewat vena orbitalis disentuhkan pada strip glukometer digital. Setelah 5 detik kadar glukosa darah akan terbaca di layar glukometer digital. Satuan kadar glukosa darah dinyatakan dalam $\mathrm{mg} / \mathrm{dL}$ (Anonimus, 2008).

\section{Menentukan kadar kolesterol darah}

Metode pengukuran kadar kolesterol sesuai dengan prosedur CHOD-PAP : Enzymatic Photometric Test sebagai berikut : larutan blank dan larutan standar/sampel disiapkan sebagai berikut : larutan blank dibuat dengan cara mencampur $10 \mu \mathrm{L}$ aquasdes dengan $1000 \mu \mathrm{L}$ reagen kolesterol; Larutan standar disiapkan dengan mencampur $10 \mu \mathrm{L}$ larutan standar dengan $1000 \mu \mathrm{L}$ reagen; Larutan sampel disiapkan dengan mencampur $10 \mu \mathrm{L}$ larutan sampel dengan $1000 \mu \mathrm{L}$ reagen. Larutan blank, larutan standar, larutan sampel diinkubasi selama 20 menit pada suhu 20$25^{\circ} \mathrm{C}$. Absorbansi larutan blank, larutan standar dan larutan sampel dibaca pada panjang gelombang $500 \mathrm{~nm}$.

$$
\text { Konesentrsi kolesterol sampel }=\frac{O D \text { sampel-OD blank }}{O D \text { Standar }- \text { OD blank }} \times \text { Konsentasi standar }
$$

\section{HASIL DAN PEMBAHASAN}

Hasil pengukuran berat badan tikus, kadar CCK, kadar glukosa darah dan kadar kolesterol darah disajikan pada Tabel 1 dan Gambar 1. Menurut Saia et al. (2014), tikus Wistar dengan rata-rata berat badan $241,08 \pm 9,07$ gram, maka kadar CCK adalah 28,23 \pm 13,39 pg/mL, dan menurut Johnson-Delaney (1996) dan Sharp dan Regina (1998), kadar normal glukosa darah tikus adalah $80 \quad-300 \mathrm{mg} / \mathrm{dL}$, kadar kolesterol darah adalah 50-135 mg/dL. Hasil penelitian ini (Tabel 1) menunjukkan bahwa berat badan rata-rata $54,60 \pm 3,36$ gram, kadar CCK adalah $259,61 \pm 104,60$, kadar glukosa darah tikus adalah $125,35 \pm 20,36 \mathrm{mg} / \mathrm{dL}$ dan kadar kolesterol $74,5 \pm 14,73 \mathrm{mg} / \mathrm{dL}$. Adanya perbedaan ini, menurut Prinz dan Andreas (2017), Perry dan Wang (2012) disebabkan karena adanya pengaturan asupan makanan. Pengaturan asupan makanan merupakan faktor terpenting yang terlibat dalam pengendalian berat badan. Kolesistokinin disekresikan sebagai pengontrol makanan di gastrointestinal yang sangat dipengaruhi oleh nutrisi yang ditelan.

Hasil analisis korelasi antara berat badan, kadar kolesistokinin plasma, kadar glukosa darah dan kadar kolesterol darah tikus menunjukkan, bahwa CCK dengan glukosa tidak berkorelasi ( $>0,528)$, Glukosa dengan CCK tidak berkolerasi $(\mathrm{p}>0,528)$, glukosa dengan kolesterol tidak berkorelasi ( $>0,913)$, kolesterol dengan CCK tidak berkorelasi ( $p>0,0,217)$, kolesterol dengan glukosa tidak korelasi $(\mathrm{p}>0,913)$ Jadi pada tikus Wistar normal umur 1 bulan CCk tidak berkorelasi dengan glukosa dan kolesterol.

Kolesistokinin disekresikan oleh sel endokrin usus sebagai respons terhadap pemberian lipid dan protein, serta bertanggung jawab untuk kontraksi kandung empedu dan sekresi enzim pankreas yang penting untuk penyerapan nutrisi. Kolesistokinin disekresikan secara lokal atau ke dalam darah mengikat reseptor spesifik pada 
kantong empedu, pankreas, lambung, atau berbagai saraf untuk merangsang kontraksi kandung empedu, sekresi enzim pankreas, menunda pengosongan lambung, mengatur rasa kenyang, dan mempotensiasi sekresi insulin (King et al., 2015; Liddle et al. 2017)

Pada tikus CCK penting dalam mengatur asupan makanan, karena CCK mempengaruhi fungsi pankreas sebagai respons terhadap makanan (Chowdhury dan Rayford, 2001). Kurangnya asupan lemak atau protein dalam diet, maka CCK disekresikan (Washington et al., 2016). Sekresi CCK dimulai saat makanan meninggalkan lambung dan memasuki usus halus (duodenum) sampai protein, lemak, dan metabolitnya telah melewati usus halus bagian atas (Liddle et al., 2017), sementara itu hormon peptide tyrosine tyrosine (PYY) dan Glucagon like peptide 1 (GLP-
1) dilepaskan saat nutrisi berlanjut melalui usus. Hal ini mengarah pada kontak langsung nutrisi dengan sel enteroendokrin untuk memicu pelepasan anorexigenik yaitu peptida. Kolesistokinin terutama distimulasi oleh lipid dan protein yang dicerna, sementara glukosa intraduodenal hanya memberikan sedikit peningkatan CCK yang bersirkulasi pada hewan yang sehat. Lipid terutama asam lemak dengan lebih dari 12 karbon (oleat) atau protein yang tidak terhidrolisis dan sebagian terhidrolisis (inhibitor tripsin atau penghambat tripsin) merangsang sekresi CCK (Prinz dan Andreas, 2017), sehingga CCK memainkan peran penting dalam transportasi dan metabolisme lipid, homeostasis glukosa dan homeostasis energi antara asupan makanan dan pengeluaran energi (King et al., 2015).

Tabel 1. Data berat badan, kadar kolesistokinin plasma, kadar glukosa darah dan kadar kolesterol darah tikus Wistar (Rattus norvegicus) jantan, umur 1 bulan

\begin{tabular}{lcccc}
\hline $\begin{array}{l}\text { No. } \\
\text { Tks }\end{array}$ & Berat Badan $(\mathrm{gram})$ & $\begin{array}{l}\text { Kadar } \\
(\mathrm{pg} / \mathrm{mL})\end{array}$ & $\begin{array}{l}\text { Kadar glukosa } \\
(\mathrm{mg} / \mathrm{dL})\end{array}$ & $\begin{array}{c}\text { Kadar Kolesterol } \\
(\mathrm{mg} / \mathrm{mL})\end{array}$ \\
\hline 1 & 53,6 & 178,39 & 100 & 48,7 \\
2 & 54,2 & 279,68 & 104 & 44,3 \\
3 & 55,8 & 456,40 & 88 & 58,2 \\
4 & 55,2 & 482,15 & 142 & 63,8 \\
5 & 58,8 & 375,41 & 115 & 59,3 \\
6 & 54,6 & 289,52 & 158 & 76,3 \\
7 & 57,5 & 251,80 & 159 & 66,6 \\
8 & 50,4 & 360,70 & 157 & 40,2 \\
9 & 53,3 & 296,73 & 122 & 85,8 \\
10 & 45,4 & 245,89 & 133 & 55,4 \\
11 & 53,5 & 337,68 & 139 & 90,1 \\
12 & 58,0 & 273,29 & 117 & 66,8 \\
13 & 54,7 & 157,39 & 144 & 61,4 \\
14 & 57,1 & 163,39 & 135 & 63,3 \\
15 & 57,0 & 127,31 & 116 & 75,8 \\
16 & 51,7 & 111,48 & 103 & 83,7 \\
17 & 56,1 & 135,00 & 106 & 83,8 \\
18 & 58,2 & 227,91 & 121 & 62,2 \\
19 & 60,1 & 193,37 & 119 & 98,9 \\
20 & 56,3 & 248,83 & 129 & 76,5 \\
\hline $\mathrm{X}+\mathrm{SD}$ & $54,60 \pm 3,36$ & $259,61 \pm 104,60$ & $125,35 \pm 20,36$ & $74,50 \pm 14,73$ \\
\hline
\end{tabular}




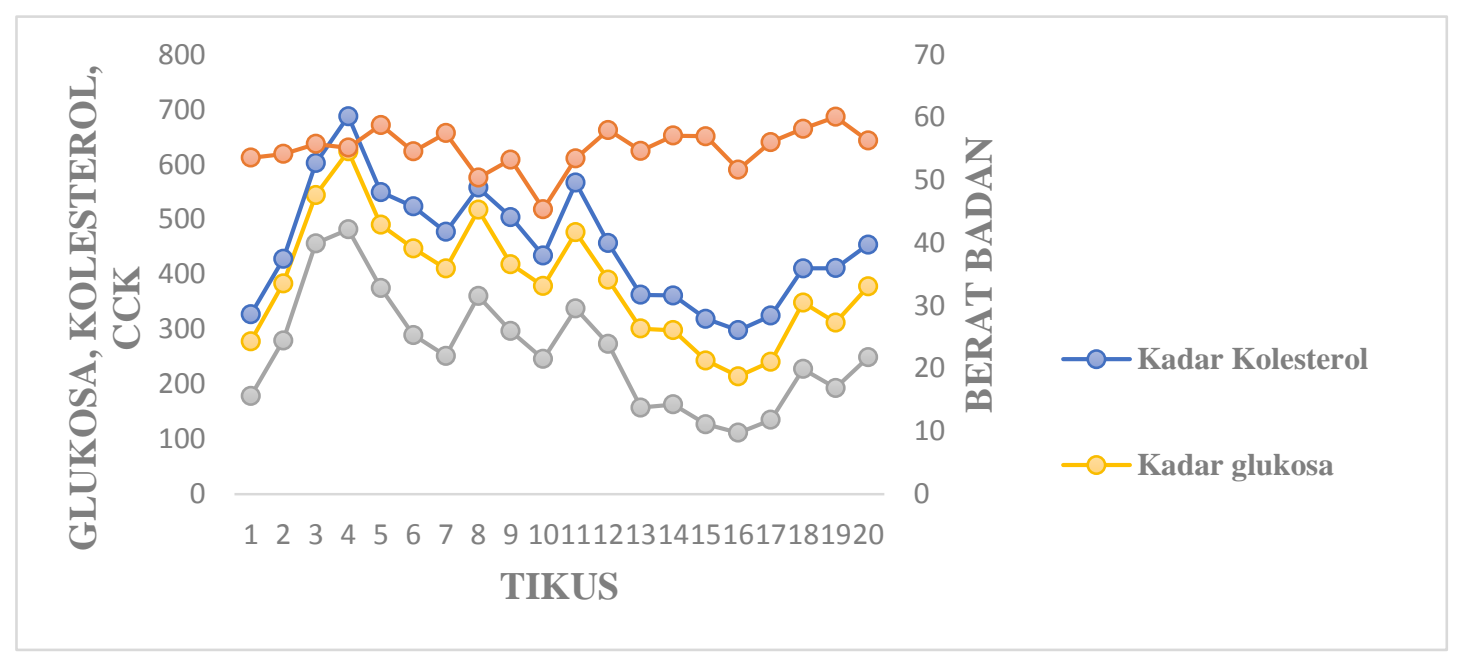

Gambar 1. Grafik korelasi antara berat badan, kadar kolesistokinin plasma, kadar glukosa darah dan kadar kolesterol darah tikus Wistar (Rattus norvegicus) jantan, umur 1 bulan

Saraf yang terlibat dalam pengendalian asupan makanan dan berat badan. Respons CCK terhadap makanan lipid diet penting untuk transportasi lipid dan pengeluaran energi untuk mengendalikan berat badan. Apabila CCK mengalami peningkatan, maka dapat menyebabkan duodenum menurunkan produksi glukosa dari perubahan peningkatan sirkulasi insulin. Selanjutnya CCK duodenum memerlukan aktivasi usus reseptor CCK dan aksis saraf usus-otak-hati untuk menurunkan produksi glukosa (Bi dan Moran, 2016).

Hasil penelitian ini menunjukkan bahwa pada tikus normal kadar CCK plasma tidak berkorelasi dengan kadar glukosa darah dan kadar kolesterol darah. Diharapkan pada penelitian lebih lanjut dengan pengaturan kekurangan atau kelebihan asupan makanan yang mengandung lemak atau protein akan diperoleh kejelasan keterkaitan antara CCK dengan glukosa dan kolesterol.

\section{KESIMPULAN}

Hasil penelitian menunjukkan bahwa berat badan rata-rata tikus adalah 54,6 $+3,36$ gram, kadar kolesistokinin 259,61 $\pm 104,60 \quad \mathrm{pg} / \mathrm{mL}, \quad$ kadar glukosa darah $125,35 \pm 20,36 \mathrm{mg} / \mathrm{dL}$ dan kadar kolesterol 74,5 $\pm 14,73 \mathrm{mg} / \mathrm{dL}$. Disimpulkan bahwa pada tikus normal umur 1 bulan kadar CCK plasma tidak berkorelasi dengan kadar glukosa darah dan kadar kolesterol darah.

\section{DAFTAR PUSTAKA}

Agersnap, M., Rehfeld, J.F. 2015. Nonsulfated cholecystokinins in the small intestine of pigs and rats. J. Peptides. 71:121-127

Anonimus. 2008. ACCU-CHEK Active Blood Glucose Meter. Roche Diagnostics GmbH. Sandhofer Strasse 11668305 Mannzheim Germany.

Anonimus. 2009. Cholesterol FS. DiaSys Diagnostic Systems GmbH. Alte Strasse 9 65558 Holzheim Germany.

Bi, S., Moran, T.H. 2016. Obesity in the otsuka long evans tokushima fatty rat: mechanisms and discoveries. Front. Nutr. 3:21.

Cao, B., Zhang, X., Yan, Ni., Chen, S., Li, Y. 2012. Cholecystokinin enhances visceral pain-related affective memory via vagal afferent pathway in rats. Molecular Brain. 2012. 5:19.

Chowdhury, P., Rayford, P.L. 2001. Effect of food restriction on plasma cholecystokinin levels and exocrine pancreatic function in rats. Ann Clin Lab Sci Fall. 31(4)376-382. 
Johnson-Delaney, C. 1996. Exotic animal companion medicine handbook for veterinarians. Zoological Education Network.http://www.ratfanclub.org/values.h $\underline{\mathrm{tml}}$

King, A., Yang, Q., Huesman, S., Rider, T, Lo, C.C. 2015. Lipid transport in cholecystokinin knockout mice. Physiology \& Behavior. 151:198-206.

Liddle, R.A, Lamont, J.T., Grover, 2017. Physiology of cholecystokinin.https://www.uptodate.com/c ontents/physiologycholecystokinin\#H13015 $\underline{1371}$

Malendowicz, L.K, Nowak, M., Gottardo, L., C.T.M., Nussdorfer, G.G. 2001. Cholecystokinin stimulates aldosterone secretion from dispersed rat zona glomerulosa cells, acting through cholecystokinin receptors 1 and 2 coupled with the adenylate cyclase-dependent cascade. Endocrinol. 142, 10, 4251-4255.

Perry, B., Wang, Y. 2012. Appetite regulation and weight control: the role of gut hormones. J.Nutrition and Diabetes, 2, p.26.

Poosti, R., di Malta, L., Gagne, D., Bernad, N., Galleyrand, J.C, Escrieut, C., SilventePoirot, S., Fourmy, D., Martinez, J. 2000. The third intracellular loop of the rat and mouse cholecystokinin-A receptors is responsible for different patterns of gene activation. Molecular Pharmacol 58(6):1381-1388.

Prinz, P., Andreas, A. 2017. control of food intake by gastrointestinal peptides: mechanisms of action and possible modulation in the treatment of obesity. Journal of Neurogastroenterology and Motility, 23(2): 180-196.

Saia, R.S., Mestriner, F.L., Bertozi, G., Cunha, F.Q., Cárnio, E.C. 2014. Cholecystokinin inhibits inducible nitric oxide synthase expression by lipopolysaccharide-stimulated peritoneal macrophages. J.Mediators Inflamm. 2014.

Sekiguchi, T. 2016. Comparative endocrinology for basic and clinical research. Handbook of hormones. P.177-178, e20B-1-e20B-3.
Sharp, P.E., LaRegina, M.C. 1998. The laboratory RAT. CRC Press LLC. Boca Raton, Boston, London, New York, Washington, DC. p.16.

Washington, M.C., Mhalhal.T.R., Sayegh, A.I. 2016 Cholecystokinin-33, but not cholecystokinin-8 shows gastrointestinal site specificity in regulating feeding behaviors in male rats. Hormones and Behavior. 85:3642. 